\title{
Antioxidant Content, Capacity and Retention in Fresh and Processed Cactus Pear (Opuntia ficus-indica and O. robusta) Fruit Peels From Different Fruit-Colored Cultivars
}

\author{
Maryna De Wit ${ }^{1 *}$, Alba Du Toit ${ }^{2}$, Gernot Osthoff ${ }^{1}$ and Arno Hugo ${ }^{1}$ \\ ${ }^{1}$ Department of Microbial, Biochemical and Food Biotechnology, Faculty of Natural and Agricultural Sciences, University of \\ the Free State, Bloemfontein, South Africa, ${ }^{2}$ Department of Consumer Science, Faculty of Natural and Agricultural Sciences, \\ University of the Free State, Bloemfontein, South Africa
}

OPEN ACCESS

Edited by:

Wee Sim Choo,

Monash University Malaysia, Malaysia

Reviewed by:

Monia Ennouri,

Ministry of Higher Education and

Scientific Research, Tunisia Laurent Dufossé,

Université de la Réunion, France

*Correspondence: Maryna De Wit dewitm@ufs.ac.za

Specialty section:

This article was submitted to

Sustainable Food Processing,

a section of the journal

Frontiers in Sustainable Food Systems

Received: 01 April 2020

Accepted: 24 July 2020

Published: 04 September 2020

Citation:

De Wit M, Du Toit A, Osthoff G and Hugo A (2020) Antioxidant Content

Capacity and Retention in Fresh and

Processed Cactus Pear (Opuntia ficus-indica and O. robusta) Fruit Peels From Different Fruit-Colored Cultivars.

Front. Sustain. Food Syst. 4:133.

doi: 10.3389/fsufs.2020.00133
During processing, the peels and seeds from cactus pear fruits are usually discarded. These "waste" products contain valuable bioactive compounds. This study investigated the antioxidant content and antioxidant potential of fresh and processed (juiced, dried, preserved, and chutney) cactus pear fruit peels from different fruit-colored cactus pear cultivars. Cactus pear peels contained high levels of antioxidants and demonstrated high antioxidant activity. The highest contents were found in dried peels, while the preserves had the lowest contents. Products on the positive side of Factor 1 of the PCA plot are mostly associated with the antioxidants PCA analysis showed that products, rather than cultivars, seem to cluster together, e.g., juices and fresh peels, chutneys, preserves and dried peels. Robusta and its products cluster together, as well as with betalains. The \% DPPH, carotenoids and phenolics are grouped together, with \% chelating activity closely correlated with ascorbic acid. Dried products from all cultivars correlated closely with $\%$ DPPH, carotenoids and phenolics, especially dried peel from Gymno-Carpo (orange), Ofer (orange), Meyers (red), and Nepgen (green). Red and orange preserves formed a cluster, while green preserves and chutney from all cultivars clustered together, as did fresh peels and juices. Purple fruit peel products had the highest \% DPPH, \% chelating activity, betalains, phenolic compounds and carotenes. Ascorbic acid dominated in orange and red fruit peels. Purple and orange were the colors of cactus pear fruit cultivars that might be the best choice in terms of antioxidant content. The cultivar that presented the best fruit peel from an antioxidant point of view for preservation was Robusta. Cactus pear fruit peels should be included in processed products such as juice, dried fruit and chutneys. These processed products are multi-component food ingredients and are therefore multi-component nutraceuticals which retained their antioxidant properties.

Keywords: ascorbic acid, betalains, carotenoids, phenolics, prickly pear peels 


\section{INTRODUCTION}

The cactus pear (Opuntia ficus-indica) originated from Mexico (Inglese et al., 2002) and is a member of the Cactaceae family. It is found in Latin America, South Africa and the Mediterranean. The cactus pear plant is a fleshy bush or small tree and the fruit is an elongated oval-shaped berry with a thick peel that accounts for $33-55 \%$ of the fruit, while the pulp makes up about 45-67\% (Piga, 2004; Arrizon et al., 2006). The pulp contains $2-10 \%$ seeds, which are good sources of unsaturated edible oils (López-González et al., 1997; De Wit et al., 2016, 2017, 2018). The fruit is usually consumed fresh, however interest to process it into different products such as juice, jam, marmalade and jelly is increasing (Cardador-Martínez et al., 2011). During processing, the peels and seeds are usually discarded. These agro-industrial "waste" products contain valuable bioactive compounds and dietary fiber (Pimienta-Barrios, 1994; AmayaCruz et al., 2018). In general, cactus pear fruit peels contain total soluble solids (TSS) $\left(8.03-15.4{ }^{\circ} \mathrm{Brix}\right)$, organic acids (titratable acidity, TA, of $0.61-3.4$ g.L $\left.\mathrm{L}^{-1}\right)$, protein $(1.53 \% \mathrm{DW})$, lipids $(0.32 \%$ DW), total fibers $(5.83 \% \mathrm{DW})$, ash $(3.4 \% \mathrm{DW})$, fructose (2781.8 g. $\mathrm{L}^{-1}$ ) and glucose (57-128 g.L $\mathrm{L}^{-1}$ ) (De Wit et al., 2010; Hernández García et al., 2020). Sucrose is also present. Dietary fibers include both soluble (mucilage and pectin) and insoluble fibers (lignocellulosic material). Processing of common fruits generates large amounts of peels which are known to contain high dietary fiber contents. Furthermore, Pérez-Jiménez and Saura-Calixto (2018) reported fruit peels as sources of nonextractable polyphenols or macromolecular antioxidants. The most commonly cultivated Opuntia spp. include O. ficus-indica, $O$. megacantha, O. streptacantha and O. amyloclaea (Galati, 2001). Fruits and young cladodes of Opuntia have traditionally been used to treat diabetes, indigestion, hypertension, asthma, oedema and burns in folk medicine (Pimienta-Barrios, 1994; Galati et al., 2003; Stintzing et al., 2005).

The health-promoting and health- improving capacity of cactus pear fruit pulp is of interest (Kuti, 2000; Stintzing et al., 2005; Arrizon et al., 2006) especially for the development of nutraceutical and functional foods (El-Said et al., 2011) and is attributed to bioactive compounds such as phenolic and polyphenolic compounds, pectin, carotenoids, betalain pigments, vitamins, and enzymes with antioxidant properties (Kuti, 2004; Abou-Elella and Ali, 2014; Patil and Dagadkhair, 2019). Polysaccharides contributing to antioxidant values in O. macrorhiza peels were reported by Amamou et al. (2020). Antioxidant properties of betalains could be related to and have synergistic effects with other bioactive molecules such as tocopherols, organic acids, reducing sugars and polyunsaturated fatty acids (Pérez-Jiménez and Saura-Calixto, 2018). The presence of antioxidants in plants makes it beneficial for health to consume plant products. Antioxidants are compounds that protect cells against reactive oxygen molecules' oxidative effects. Oxidative stress is caused by an imbalance between these reactive oxygen species and antioxidant content. This oxidative stress causes cellular damage and leads to conditions and ailments such as diabetes, cancer, CVD, aging and neurodegenerative disorders (Panche et al., 2016). Fruit products are important for the prevention of degenerative diseases such as cancer, hyperglycaemia, hypercholesterolemia, arteriosclerosis, diabetes and gastric diseases because of the presence of antioxidant phenolic compounds in cactus pear plants (Butera et al., 2002; Stintzing et al., 2005). The antioxidant activity of cactus pear fruit is double than that of apples, pears, bananas, tomatoes and white grapes and is comparable to that found in red grapes, grapefruit and oranges (Cerezal and Duarte, 2005). El-Said et al. (2011) pointed out that it is known that fruit contains vitamin C but studies on other antioxidants in peels are lacking. These authors also pointed out that one of the major needs within the prickly pear industry is the development of new processed products, especially fruit by-products. These "new" functional components will open up new possibilities to add value. Fermentation could be used to develop new food products, such as wine, vinegar and balsamic vinegar (acetic acid fermentation) (Sáenz, 2015). Innovative extraction techniques such as ultrasound-assisted extraction of phytocompounds could be employed (as was done in dragon fruit peels) (Bhagya Raj and Dash, 2020). On a larger and industrial scale, biofuels, i.e., bioethanol could be produced from organic materials containing carbohydrates and have high sugar contents as well as from the lignocellosic material (consisting of lignin, hemicellulose and cellulose) using saccharification and fermentation by enzymes simultaneously (Casabar et al., 2019) as was done for pineapple peels.

Currently, limited literature on the antioxidant content of cactus pear fruit peels is available. Cardador-Martínez et al. (2011) reported on the revalorization of cactus pear by-products as a source of antioxidants. These authors suggested that some of these waste product constituents should be obtained and used as additives in the food, pharmaceutical and cosmetic industries. Cactus pear peels have been reported useful as a marmalade (El Kossori et al., 1998), while the seeds were a source of dietary fiber (Ramadan and Mörsel, 2003a), oil (López-González et al., 1997; Habibi et al., 2002; Ramadan and Mörsel, 2003b; De Wit et al., 2016, 2017, 2018), and D-xylan (Habibi et al., 2002, 2005). Cactus pear peels have been used for the extraction of phenolic compounds and polysaccharides (Melgar et al., 2017; PérezJiménez and Saura-Calixto, 2018; Amamou et al., 2020) and are a rich source of dietary fiber, vitamin $\mathrm{C}$ and betalains (JiménezAguilar et al., 2015). These compounds have been reported to have a positive affect against coronary heart disease, high blood pressure, diabetes and cancer (to name a few).

Cactus pear fruit is susceptible to microbial spoilage. Preservation techniques are applied to extend the storage life and also to diversify the processed products (Joubert, 1993; Piga et al., 2003; Sáenz et al., 2004). It was previously assumed that processing would damage the antioxidant content and potential of cactus pear fruits. According to Sacchetti et al. (2008), the antioxidant potential of processed fruit products, after processing and during storage, is mostly dependent on the quality of the fresh fruit, processing procedures and storage conditions. Tesoriere et al. (2005) reported that the vitamin $\mathrm{E}$ and betalains appeared to be unaffected by fruit processing. Piga (2004) described the ascorbate-sparing effect of polyphenols. Ryan and Prescott (2010) uncovered a whole new research question on whether heat treatments affect 
antioxidant capacity in processed fruit products. Some juices studied had higher antioxidant capacity in long life (heattreated) versions. This contradicts traditional beliefs that the scavenging ability of individual antioxidants is destroyed by heat. Ryan and Prescott (2010) provided three explanations for the protection of the antioxidants: firstly, antioxidant potential increased after processing because more antioxidant components are released due to the heat that disrupts the cell walls. Secondly, heat treatments destroy oxidative enzymes that would normally destroy antioxidants. Thirdly, during heat treatments new structural groups are formed which enhance antioxidant potential. The third reason was proposed as being the most probable. It was also found that antioxidant potential of gallic acid increased after heat treatments because new hydroxyl groups are formed due to structural changes of the polyphenols. These structural changes cause the antioxidant to be more stable to $\mathrm{pH}$, which allow it to continue its activity throughout the digestive tract. In a study done by Lee et al. (2008) the effect of home processing and light exposure on flavonoid content was evaluated. It was found that "cooking" methods had varying effects on the content and that exposure to fluorescent light increased the content.

Currently very little information is available on processing effects on the antioxidant content of cactus pear fruit peels. In a recent study of Barba et al. (2017) it was speculated whether phytochemicals can loose their properties, or be transformed into anti-nutrients, depending on the processing conditions. The authors concluded that processing and preservation techniques strongly influence the stability of phytochemicals present in Opuntia fruits. Conventional and novel non-thermal technologies are efficient to recover high contents of valueadding compounds of Opuntia fruit by-products and wastes (such as ultrasonic extraction as was mentioned earlier for dragon fruit peels). This current study was done to firstly obtain a basic profile of the main antioxidants present (contents) and its antioxidant potential and to investigate if different fruit peel colors (tonalities) influence this profile. Secondly, it was attempted to determine if these identified antioxidants would be retained in the products after the peels were processed into different products to prolong shelf-life. The data is presented on an "as is" basis, implicating the antioxidant contents of the final products as the consumer would use them. Therefore, in the current study, the antioxidant content (betalain-, ascorbic acid-, carotenoid-, and total phenolic contents) and antioxidant potential (\% DPPH scavenging and \% Fe chelating activity) of fresh and processed (juiced, preserved, dried and chutney) cactus pear fruit peels from different fruit-colored cactus pear cultivars was investigated. Different preservation methods were applied to the peel of each of the five cultivars, in order to obtain results for antioxidant content and potential in the peels of the fruit, after preservation methods were applied. It was important to produce marketable products for the South African public. The products had to be well-known, everyday food that South Africans are accustomed to. In South-Africa, the Opuntia ficusindica plant is mainly cultivated for the fruit destined for the local and European markets. There is currently a small but well developed commercial sector in South-Africa, but the plant as a whole is mainly under-utilized and under-valued. It is only through research such as this study that the true value of this easily cultivated plant may be realized as a healthy food resource. These processed products could be regarded as multi-component nutraceuticals. Published results on a previous study by De Wit et al. (2019) on the antioxidants of the different tissue types (vegetal parts) are included as a starting point to this study for comparison purposes of fresh peel. It was therefore important to compare the results of the products manufactured from the peels of different cultivars with fresh unprocessed control peels.

\section{Materials and Methods Fruit Collection}

Fruit was collected at an experimental orchard to the West of Bloemfontein ( $29^{\circ} 10^{\prime} 53^{\prime} \mathrm{S}, 25^{\circ} 58^{\prime} 38^{\prime \prime}$ E), Free State Province, South Africa (De Wit et al., 2010). The complete randomized block designed orchard consisted of 42 spineless cactus pear cultivars. The plants were $3 \mathrm{~m}$ apart in rows spaced at $5 \mathrm{~m}$, resulting in 666 plants ha ${ }^{-1}$. Treatments were replicated twice with five plants per treatment (Coetzer and Fouché, 2015). Fruits were picked at the $50 \%$ color-break stage to ensure an even degree of ripeness and also because it is the point of optimum sugar content $\left({ }^{\circ}\right.$ Brix) and firmness in this non-climacteric fruit (does not ripen or change after harvesting) (Felker et al., 2008). This is also considered the commercial maturity (50\% external color) stage, when both the parenchyma and chlorenchyma of the peel portions have similar colouration as the edible pulp portion (Felker et al., 2008). Fruit size ranged from 67 to 216 g. Fruit from four cultivars of the O. ficus-indica species, namely Meyers (red), Gymno-Carpo (orange), Ofer (orange), and Nepgen (green), and one cultivar from the Opuntia robusta specie, namely Robusta (purple) were picked, refrigerated at $4 \pm 1^{\circ} \mathrm{C}$ and processed within 3 days after harvesting (De Wit et al., 2010; Du Toit et al., 2015, 2018b). The different colored phenotypes (cultivars) of cactus pear fruit are related to betalin- and carotenoid content (Cano et al., 2007; Amaya-Cruz et al., 2018) and green, orange, yellow, red and violet (purple) colors are available due to the large genetic variability. It is important to note that the same methodology was used as reported in the study of De Wit et al. (2018) on cactus pear fruit pulp. The current study however, makes use of the fruit peels and although the peel is part of the fruit, the physiological composition differs with regard to the cellular structure. The cell wall construction is different, resulting in higher fiber content in the peel and more juice in the pulp (fruit). It is therefore accepted that the chemical content of the pulp and peel will be different (Salisbury and Ross, 1991).

\section{Sample Preparation}

Working with cactus pear fruit is problematic as it is covered with hair-like thorns (glochids) that may cause severe discomfort when penetrating the skin. The glochids were consequently removed by brushing under cold running water while held with tongs. All fruit were then blanched in boiling water for $30 \mathrm{~s}$, followed by cooling in cold water $\left(4 \pm 1^{\circ} \mathrm{C}\right)$. This allowed bare handed handling and easy peeling of the outer skin from the peel, similar as is practiced for tomatoes (Brown, 2008). After skin removal, the peel was separated from the fruit by the cut 
and tear method. Depending on the cultivar, the amount of peel may vary between 40 and $50 \%$ of the whole fruit. Juice, dried peel, preserves and chutney were prepared for each cultivar replication in triplicate. Juice was the first choice as it would be the most obvious product to market since the fruit has such vibrant colors. Drying is the oldest and one of the easiest preservation methods and therefore had to be included in the study. Chutney was included as this method includes sugar, acid as well as spices in the preservation technique. Preserved peel in syrup was included due to its visual appeal and being a very tasty product (Food Preservation, 1986). Since the formulation of products such as peel juice, chutney and preserved peels differ drastically it is not possible to compare products on the same peel content. Since formulations contain different ingredients, the logical and possible way to evaluate results is to compare the manufactured products on an "as is" basis (as the consumer consume it) with the fresh peels as was done in this study.

\section{Peel Juice Preparation}

For juice preparation, the peels of 20 fruits of each cultivar were liquidized in a Milex 4-in-1 multi-purpose Mean Juice Machine (Model MMJ004) (low speed setting for soft fruit) for $60 \mathrm{~s}$. The juice was pasteurized in a water-bath until the internal temperature reached $72^{\circ} \mathrm{C}$ and kept for $5 \mathrm{~min}$ at $72^{\circ} \mathrm{C}$, shocked in cold water and then frozen at $-20 \pm 1^{\circ} \mathrm{C}$.

\section{Dried Peels}

For preparation of dried peels, ten fruits of each cultivar were washed and peeled and the peels were blanched at $80^{\circ} \mathrm{C}$ for $5 \mathrm{~min}$. The fruit peels were cut into slices $(7.5 \pm 0.5 \mathrm{~mm})$, dried in a convection oven at $70 \pm 1{ }^{\circ} \mathrm{C}$ for $18 \mathrm{~h}$ (Kuti, 2000) and then vacuum packed and frozen $\left(-20 \pm 1^{\circ} \mathrm{C}\right)$ until further analysis. The peels were dried from an initial moisture content of $\approx$ $80-89 \%$ until a final moisture content of between $\approx 9-18 \%$.

\section{Preserved Peels}

Preserved peels (a sugar-based product) were prepared as follows: 20 peels of each cultivar were weighed and jarred according to the open-kettle method (Food Preservation, 1986). The peels were cooked in boiling water for $5 \mathrm{~min}$ until just tender. It was transferred into prepared boiling syrup [ $250 \mathrm{ml}$ sugar (sucrose) dissolved in $500 \mathrm{ml}$ water] for $10 \mathrm{~min}$ to allow the syrup to permeate through the peels. The preserved peels were transferred to hot, sterilized jars. The jars were filled with boiling syrup to the brim in order to exclude air from the jar. Metal lids were used to cover the jars and screwed down tightly. The steam from the fruit condensed and formed a vacuum that completed the seal (Food Preservation, 1986).

\section{Chutney Preparation}

Chutney is a low $\mathrm{pH}$ (acid) preserved relish-type condiment using sugar, acid and heating. Chutney was prepared from peels as follows: the peels of 20 cactus fruits of each cultivar were washed, weighed and liquidized as explained above. The liquidized peel was weighed and the amounts of added ingredients were calculated according to the following formula: $69 \%$ fruit peels, $13.8 \%$ sugar, $12.95 \%$ vinegar, $4.2 \%$ seasoning and flavoring, which consisted of cayenne pepper (0.01\%), minced onion $(3.45 \%)$, salt $(0.22 \%)$, powdered ginger $(0.22 \%)$, powdered mustard $(0.06 \%)$ and powdered garlic $(0.24 \%)$ (Food Preservation, 1986). All the ingredients were added to a stainless steel saucepan and allowed to boil slowly until it was thick and dropped off the spoon in flakes and had the consistency of jam. It was stirred occasionally using a wooden spoon. The prepared chutney was poured into hot sterilized jars and sealed immediately, labeled and stored at room temperature. Antioxidants from spices reportedly include flavonoids, phenolic acids, lignins, essential oils, and alkaloids (Yashin et al., 2017). Herbs and spices have therapeutic effects such as anti-carcinogenic, anti-diabetic, anti-ulcer, antiinflammatory properties and protect against endocrine disease, oxidative damage to red blood cells and renal disease. In a study done by Hossain et al. (2008), the antioxidant capacity of 30 spices and herbs were evaluated, with garlic ranking the lowest. According to this ranking, the antioxidant capacity of the spices used in chutney preparation, ranks as follows: onion $>$ ginger $>$ cayenne pepper $>$ mustard $>$ garlic. The contribution of each individual spice used was not determined, but it contributed to the antioxidant capacity of the chutney product as a whole.

\section{Antioxidant Measurements}

For determination of iron chelating activity, DPPH radical scavenging, betalain content, ascorbic acid content and total phenolic compound content, aqueous extracts were prepared for all the processed products. The products were liquidized with $50 \%$ distilled $\mathrm{H}_{2} \mathrm{O}$, strained and the volume of the filtrate determined and aliquots frozen at $-20 \pm 1^{\circ} \mathrm{C}(\mathrm{Du}$ Toit et al., 2018a,b). A hexane/acetone/ethanol extract was prepared from all the processed products for carotenoid determination. Two grams of product (tissue) was homogenized with $10 \mathrm{ml}$ hexane/acetone/ethanol (50:25:25) mixture, centrifuged and the hexane layer then recovered (Du Toit et al., 2018a,b).

\section{Chelating Activity}

Chelating activity of the antioxidant was determined using an amended method (Sumaya-Martínez et al., 2011) of the method of Gülçin et al. (2007). One hundred microliters of aqueous extract, containing $50 \mu \mathrm{l}$ ferric (II) chloride solution $(2 \mathrm{mM})$ and $4.5 \mathrm{ml}$ methanol was vortexed for $10 \mathrm{~s}$. Two-hundred $\mu \mathrm{l}$ ferrozine $(5 \mathrm{mM})$ was added and the solution was centrifuged. Blank solutions containing both aqueous extract and methanol were also prepared and were included to make the absorbance measurement of the purple fruit possible. Absorbance of the supernatant was determined at $562 \mathrm{~nm}$ using a Genesys 10 Vis Thermospectronic spectrophotometer and the chelating activity (as \% FW) determined.

\section{DPPH Radical Scavenging Activity}

DPPH (2,2'-diphenyl-1-picrylhydrazyl) was determined according to the methods of Morales and Jiménez-Pérez (2001) and Sumaya-Martínez et al. (2011). Five-hundred $\mu \mathrm{l}$ of the DPPH solution $\left(7.4 \mathrm{mg} / 100 \mathrm{ml}^{-1}\right.$ ethanolic solution) was added to $100 \mu \mathrm{l}$ of the aqueous extracts, vortexed for $10 \mathrm{~s}$, left to stand for $1 \mathrm{~h}$ and then centrifuged at $13416 \mathrm{xg}$ for $5 \mathrm{~min}$ at $4^{\circ} \mathrm{C}$. Absorbance was measured at $517 \mathrm{~nm}$ with a Genesys 10 Vis 
Thermospectronic spectrophotometer (Gülçin et al., 2007) using a blank solution containing aqueous extract and ethanol. Results were expressed as \% FW.

\section{Betalains}

Betalains were determined according to the methods reported by Castellanos-Santiago and Yahia (2008) and Stintzing et al. (2005). The aqueous extract was centrifuged at $13416 \mathrm{xg}$ for $5 \mathrm{~min}$ in a 12 Hettich centrifuge. The photometric quantification of the supernatant was done on a Genesys 10 Vis Thermo Spectronic spectrophotometer (Stintzing et al., 2005). Measurements were done in triplicate and the betalain content [which comprises of the red-violet betacyanins $(\mathrm{Bc})$ and the yellow betaxanthins $(\mathrm{Bx})]$ was calculated according to the following equation. Thereafter all values were converted to $\mathrm{mg} / \mathrm{kg}$ fresh weight $(\mathrm{FW})$ :

$\mathrm{Bc} / \mathrm{Bx}(\mathrm{mg} / \mathrm{g})=(A \times \mathrm{DF} \times \mathrm{MW} \times 1,000) /(\epsilon \mathrm{x} l)(\mathrm{De}$ Wit et al., 2019).

\section{Ascorbic Acid}

Ascorbic acid was determined by means of titration according to James (1995). The aqueous cactus pear product extracts were titrated with $0.04 \%$ 2,6 dichlorophenolindophenol solution. Results were expressed as mg/100 g FW.

\section{Carotenoids}

Carotenoid content was determined after the samples were homogenized with $10 \mathrm{ml}$ hexane:acetone:ethanol (50:25:25,v/v) and centrifuged at $5668 \mathrm{xg}$ at $4^{\circ} \mathrm{C}$ for $5 \mathrm{~min}$, after which the toplayer of hexane was recovered and the volume adjusted to $25 \mathrm{ml}$ with hexane. The absorbance was measured at $450 \mathrm{~nm}$ according to the methods described by Kuti (2004) and Fernández-López et al. (2010) using an extinction coefficient of $\beta$-carotene, E1\% = 2590. Results were expressed as $\mu \mathrm{g} / \mathrm{g}$ FW.

\section{Total Phenolics}

Total phenolic content was determined using $2 \mathrm{~g}$ of the aqueous extract, which was centrifuged, and $0.2 \mathrm{ml}$ of the extract was combined with $1 \mathrm{ml}$ Folin-Ciocalteu reagent and $0.8 \mathrm{ml}$ sodium carbonate solution. Absorbance was read at $765 \mathrm{~nm}$ in a Genesys 10 Vis Thermospectronic spectrophotometer after $30 \mathrm{~min}$. The polyphenol content was expressed as milligrams of gallic acid equivalents per liter ( $\mathrm{mg} \mathrm{l}^{-1} \mathrm{GAE}$ ), following a calibration curve made with pure gallic acid at 0,50, 100, 150, 200, 250, 300, and $350 \mathrm{mg} \mathrm{l}^{-1}$ (Kuti, 2000). The units were expressed as mg/kg FW.

\section{Statistical Analysis}

Analyses were done on the two replications per cultivar. Three replications of each type of product were manufactured. Results were expressed on an as is basis of the end products, as it would be consumed by the consumer. The NCSS Statistical Software package (version 11.0.20) was used for statistical analysis. Results were expressed as mean \pm standard deviation. The effect of cultivar and processing method on antioxidant properties of cactus pear fruit peels was analyzed with one-way analysis of variance and the means compared with the Tukey-Kramer multiple comparison test (NCCS 11, 2018). The multivariate statistical procedure, principal component analysis (PCA) was used to investigate and simplify the relationship between products manufactured from different colored fruit peel samples with regard to their \% DPPH, \% chelating activity, ascorbic acid $(\mathrm{mg} / 100 \mathrm{~g})$, betacyanins $(\mathrm{mg} / \mathrm{kg})$, betaxanthins $(\mathrm{mg} / \mathrm{kg})$, betacyanins + betaxanthins $(\mathrm{mg} / \mathrm{kg})$, carotenoids $(\mu \mathrm{g} / \mathrm{g})$ and phenolics (mg/kg) (variables) (NCCS 11, 2018).

\section{RESULTS AND DISCUSSION \\ Chelating Activity}

Percentage chelating activity determines the reducing power of an antioxidant, i.e., the ability to reduce $\mathrm{Fe}^{3+}$ and the ability to donate an electron. Antioxidants cause reduction of $\mathrm{Fe}^{3+}$ to $\mathrm{Fe}^{2+}$, therefore a change of color of the solution is indicative of the reducing power of the compounds (Butera et al., 2002). Furthermore, metal ion chelating capacity plays an important role in the antioxidant mechanism, since it reduces the concentration of the catalyzing metal in lipid peroxidation (Divya et al., 2016). Chelating agents that form œ bonds with metals are effective secondary antioxidants because they reduce the redox potential, thereby stabilizing the oxidized form of the metal. Although not significantly different, the general trend observed in the $\%$ chelating activity for peels, was that the highest chelating $\%$ was observed in dried products (average 86\%) (the removal of moisture caused a more concentrated product), followed by fresh (average 78\%), juice (average 77\%), chutney (average 75\%) and the lowest in preserves (average 67\%) (Table 1). Robusta (O. robusta; purple) peel was the cultivar with the highest levels (91.4\% for preserves to $97.3 \%$ for fresh peels) throughout all the products (Table 1). In a study done by Divya et al. (2016) on bitter orange, it was found that peels provided a higher chelating activity than the pulp.

\section{DPPH Radical Scavenging}

The $\%$ DPPH indicates the free-radical scavenging activity of the antioxidants. DPPH is a protonated radical (that has absorption maxima at $517 \mathrm{~nm}$ ) that decreases with scavenging of the proton radical (Divya et al., 2016). Antioxidants react with DPPH (the nitrogen-centered free radical) that convert to 1,1 diphenyl-2picryl hydrazine due to their hydrogen donating ability. This will intercept the propagation of the free radical chain of oxidation and will form thereby stable end products. The DPPH assay for antioxidant activity is measured by a decrease in the absorbance when the DPPH radical receives a hydrogen radical or an electron from an antioxidant compound to become a stable diamagnetic molecule (Butera et al., 2002). According to the \% DPPH data, in general, the average values for chutney, dried and fresh peels were the highest and almost similar (96\%,95\%, 93\%, respectively) (Table 1). Chutney had higher values ( 94.6 for Gymno-Carpo to 97.3\% for Robusta) than dried (93.3 for Nepgen to $95.6 \%$ for Meyers) and fresh (91.2 for Gymno-Carpo to $96.3 \%$ for Meyers) cactus pear peels. The values for fresh, dried and chutney did not differ significantly, but juice and preserves were significantly lower, with preserves having the lowest values (average in juice $89 \%$ vs. average in preserves $77 \%$ ). Robusta had the highest values for preserves and juice, while Meyers had the highest values for fresh and dried products, although by very slight margins. Percentage DPPH levels for peels were higher (89.9\% average) 
TABLE 1 | The effect of cultivar and product type on the antioxidant properties of fresh and processed cactus pear peels.

\begin{tabular}{|c|c|c|c|c|c|c|c|c|c|}
\hline Product & Cultivar & $\begin{array}{c}\text { Chelating activity } \\
(\%)\end{array}$ & DPPH (\%) & $\begin{array}{l}\text { Ascorbic acid } \\
(\mathrm{mg} / 100 \mathrm{~g})\end{array}$ & $\begin{array}{l}\text { Betacyanins } \\
(\mathrm{mg} / \mathrm{kg})\end{array}$ & $\begin{array}{l}\text { Betaxanthins } \\
(\mathrm{mg} / \mathrm{kg})\end{array}$ & $\begin{array}{c}\text { Betacyanins + } \\
\text { Betaxanthins } \\
\text { (mg/kg) }\end{array}$ & Carotene $(\mu \mathrm{g} / \mathrm{g})$ & $\begin{array}{l}\text { Phenolics } \\
\text { (mg/kg) }\end{array}$ \\
\hline \multirow[t]{5}{*}{ Fresh } & Gymno C & $72.50 \pm 9.01^{\text {abcde }}$ & $91.18 \pm 2.11^{\text {efgh }}$ & $68.04 \pm 38.66^{\text {bcde }}$ & $2.21 \pm 0.21^{\mathrm{ab}}$ & $1.55 \pm 0.15^{\mathrm{ab}}$ & $3.75 \pm 0.37^{\mathrm{ab}}$ & $3.99 \pm 1.32^{\mathrm{ab}}$ & $14.04 \pm 2.48^{\mathrm{ab}}$ \\
\hline & Meyers & $70.00 \pm 10.90^{\mathrm{abcd}}$ & $96.25 \pm 2.91^{g h}$ & $86.28 \pm 21.90^{\mathrm{de}}$ & $6.87 \pm 0.75^{\mathrm{ab}}$ & $4.81 \pm 0.53^{\mathrm{ab}}$ & $11.69 \pm 1.28^{\mathrm{ab}}$ & $1.79 \pm 0.35^{\mathrm{ab}}$ & $\begin{array}{c}58.88 \pm \\
25.60^{\text {abcdef }}\end{array}$ \\
\hline & Nepgen & $81.67 \pm 5.20^{\text {cdefgh }}$ & $91.67 \pm 1.04^{\text {efgh }}$ & $55.88 \pm 7.71^{\text {abcde }}$ & $0.89 \pm 0.37^{a}$ & $0.62 \pm 0.26^{a}$ & $1.52 \pm 0.63^{\mathrm{a}}$ & $3.46 \pm 0.40^{\mathrm{ab}}$ & $15.96 \pm 8.06^{\mathrm{ab}}$ \\
\hline & Ofer & $69.17 \pm 3.82^{\mathrm{abcd}}$ & $93.85 \pm 0.75^{\text {fgh }}$ & $64.24 \pm 16.73^{\text {abcde }}$ & $1.11 \pm 0.22^{\mathrm{a}}$ & $0.78 \pm 0.15^{\mathrm{a}}$ & $1.89 \pm 0.37^{\mathrm{a}}$ & $4.80 \pm 0.59^{a b}$ & $21.31 \pm 14.73^{\mathrm{abc}}$ \\
\hline & Robusta & $97.32 \pm 0.38^{h}$ & $91.65 \pm 0.44^{\text {efgh }}$ & $61.16 \pm 25.48^{\text {abcde }}$ & $42.62 \pm 8.79^{c}$ & $29.84 \pm 6.15^{\mathrm{c}}$ & $72.46 \pm 14.94^{c}$ & $6.06 \pm 2.83^{b}$ & $7.44 \pm 4.48^{\mathrm{a}}$ \\
\hline \multirow[t]{5}{*}{ Chutney } & Gymno C & $68.33 \pm 3.82^{\mathrm{abc}}$ & $94.55 \pm 0.62^{\text {fgh }}$ & $41.99 \pm 10.16^{\mathrm{abcd}}$ & $0.86 \pm 0.06^{a}$ & $0.60 \pm 0.04^{a}$ & $1.46 \pm 0.10^{\mathrm{a}}$ & $1.27 \pm 0.16^{a}$ & $95.41 \pm 2.80^{\mathrm{fg}}$ \\
\hline & Meyers & $66.67 \pm 5.20^{\mathrm{abc}}$ & $95.30 \pm 0.58^{\text {fgh }}$ & $35.75 \pm 7.54^{\mathrm{abcd}}$ & $3.66 \pm 1.72^{\mathrm{ab}}$ & $2.56 \pm 1.20^{\mathrm{ab}}$ & $6.22 \pm 2.92^{\mathrm{ab}}$ & $1.36 \pm 0.32^{\mathrm{a}}$ & $87.53 \pm 0.72^{\text {defg }}$ \\
\hline & Nepgen & $75.83 \pm 8.04^{\text {abcdefgh }}$ & $98.25 \pm 1.00^{h}$ & $18.39 \pm 1.16^{\mathrm{ab}}$ & $1.52 \pm 0.50^{\mathrm{a}}$ & $1.07 \pm 0.35^{a}$ & $2.59 \pm 0.85^{a}$ & $0.51 \pm 0.29^{a}$ & $69.11 \pm 17.46^{\text {bcde }}$ \\
\hline & Ofer & $72.50 \pm 2.50^{\mathrm{abcde}}$ & $94.57 \pm 0.56^{\mathrm{fgh}}$ & $27.22 \pm 5.43^{\mathrm{abc}}$ & $0.65 \pm 0.10^{a}$ & $0.45 \pm 0.07^{a}$ & $1.10 \pm 0.17^{a}$ & $0.66 \pm 0.26^{a}$ & $93.26 \pm 1.95^{\mathrm{fg}}$ \\
\hline & Robusta & $94.29 \pm 0.66^{\text {efgh }}$ & $97.34 \pm 0.15^{h}$ & $37.98 \pm 6.98^{\mathrm{abcd}}$ & $6.38 \pm 0.75^{\mathrm{ab}}$ & $4.47 \pm 0.53^{\mathrm{ab}}$ & $10.85 \pm 1.28^{\mathrm{ab}}$ & $1.89 \pm 0.65^{\mathrm{ab}}$ & $47.91 \pm 7.93^{\text {abcdef }}$ \\
\hline \multirow[t]{5}{*}{ Dried } & Gymno C & $79.17 \pm 3.82^{\text {bcdefgh }}$ & $94.61 \pm 1.12^{\mathrm{fgh}}$ & $78.65 \pm 28.3^{\text {cde }}$ & $2.51 \pm 0.75^{\mathrm{ab}}$ & $1.76 \pm 0.52^{\mathrm{ab}}$ & $4.27 \pm 1.27^{\mathrm{ab}}$ & $81.92 \pm 2.83^{\mathrm{de}}$ & $87.78 \pm 9.52^{\text {defg }}$ \\
\hline & Meyers & $95.20 \pm 0.13^{\text {efgh }}$ & $95.63 \pm 1.21^{\text {fgh }}$ & $66.87 \pm 31.53^{\mathrm{bcde}}$ & $4.57 \pm 2.75^{\mathrm{ab}}$ & $3.20 \pm 1.93^{\mathrm{ab}}$ & $7.77 \pm 4.68^{\mathrm{ab}}$ & $81.27 \pm 0.56^{\mathrm{de}}$ & $100.96 \pm 59.49^{f g}$ \\
\hline & Nepgen & $85.00 \pm 9.01^{\text {cdefgh }}$ & $93.33 \pm 3.63^{\mathrm{efgh}}$ & $63.23 \pm 15.88^{\text {abcde }}$ & $0.33 \pm 0.23^{\mathrm{a}}$ & $0.23 \pm 0.16^{a}$ & $0.56 \pm 0.38^{\mathrm{a}}$ & $78.72 \pm 2.76^{d}$ & $78.52 \pm 19.92^{\text {cdefg }}$ \\
\hline & Ofer & $74.17 \pm 7.22^{\text {abcdefg }}$ & $94.66 \pm 1.48^{\mathrm{fgh}}$ & $47.58 \pm 18.25^{\mathrm{abcd}}$ & $1.65 \pm 0.72^{\mathrm{ab}}$ & $1.16 \pm 0.50^{\mathrm{ab}}$ & $2.81 \pm 1.22^{\mathrm{ab}}$ & $83.31 \pm 3.50^{e}$ & $89.23 \pm 8.81^{\mathrm{efg}}$ \\
\hline & Robusta & $96.46 \pm 1.21^{g h}$ & $94.71 \pm 0.17^{\mathrm{fgh}}$ & $109.46 \pm 27.80^{\mathrm{e}}$ & $42.47 \pm 12.81^{\mathrm{C}}$ & $29.73 \pm 8.97^{c}$ & $72.20 \pm 21.78^{c}$ & $72.78 \pm 3.20^{\circ}$ & $126.82 \pm 39.66^{9}$ \\
\hline \multirow[t]{5}{*}{ Juice } & Gymno C & $73.33 \pm 14.65^{\text {abcdef }}$ & $88.37 \pm 5.38^{\text {defg }}$ & $33.07 \pm 17.67^{\mathrm{abcd}}$ & $0.59 \pm 0.11^{a}$ & $0.42 \pm 0.08^{a}$ & $1.01 \pm 0.19^{a}$ & $1.07 \pm 0.01^{\mathrm{a}}$ & $\begin{array}{c}59.56 \pm \\
11.97^{\text {abcdef }}\end{array}$ \\
\hline & Meyers & $69.17 \pm 15.07^{\mathrm{abcd}}$ & $87.67 \pm 8.58^{\text {def }}$ & $39.12 \pm 6.07^{\mathrm{abcd}}$ & $0.91 \pm 0.48^{\mathrm{a}}$ & $0.64 \pm 0.34^{a}$ & $1.56 \pm 0.82^{a}$ & $1.38 \pm 0.13^{\mathrm{a}}$ & $47.74 \pm 9.00^{\text {abcdef }}$ \\
\hline & Nepgen & $77.50 \pm 8.66^{\text {bcdefgh }}$ & $85.41 \pm 1.08^{\mathrm{de}}$ & $35.08 \pm 6.41^{\mathrm{abcd}}$ & $0.27 \pm 0.08^{a}$ & $0.19 \pm 0.05^{a}$ & $0.46 \pm 0.13^{\mathrm{a}}$ & $0.68 \pm 0.26^{a}$ & $53.55 \pm 4.98^{\text {abcdef }}$ \\
\hline & Ofer & $69.17 \pm 2.89^{\mathrm{abcd}}$ & $88.65 \pm 3.10^{\text {defg }}$ & $29.65 \pm 2.34^{\mathrm{abc}}$ & $0.90 \pm 0.22^{\mathrm{a}}$ & $0.63 \pm 0.15^{a}$ & $1.52 \pm 0.37^{a}$ & $0.85 \pm 0.11^{a}$ & $52.06 \pm 7.89^{\text {abcdef }}$ \\
\hline & Robusta & $95.64 \pm 0.90^{\mathrm{fgh}}$ & $96.12 \pm 0.14^{g h}$ & $37.00 \pm 2.78^{\mathrm{abcd}}$ & $5.62 \pm 1.46^{\mathrm{ab}}$ & $3.93 \pm 1.02^{\mathrm{ab}}$ & $9.55 \pm 2.48^{\mathrm{ab}}$ & $3.03 \pm 0.15^{\mathrm{ab}}$ & $54.74 \pm 8.64^{\text {abcdet }}$ \\
\hline \multirow[t]{5}{*}{ Preserves } & Gymno C & $53.33 \pm 6.29^{a}$ & $68.23 \pm 2.26^{\mathrm{ab}}$ & $19.77 \pm 1.13^{\mathrm{ab}}$ & $2.65 \pm 3.58^{\mathrm{ab}}$ & $1.86 \pm 2.50^{\mathrm{ab}}$ & $4.51 \pm 6.08^{\mathrm{ab}}$ & $1.62 \pm 0.05^{\mathrm{ab}}$ & $34.73 \pm 1.82^{\text {abcde }}$ \\
\hline & Meyers & $53.33 \pm 3.82^{\mathrm{a}}$ & $82.37 \pm 1.76^{\mathrm{cd}}$ & $23.19 \pm 12.14^{\mathrm{ab}}$ & $0.88 \pm 0.11^{\mathrm{a}}$ & $0.62 \pm 0.08^{a}$ & $1.49 \pm 0.19^{a}$ & $1.60 \pm 0.04^{\mathrm{a}}$ & $31.58 \pm 17.56^{\mathrm{abcd}}$ \\
\hline & Nepgen & $79.17 \pm 1.44^{\text {bcdefgh }}$ & $75.32 \pm 2.58^{\mathrm{bc}}$ & $33.12 \pm 11.91^{\mathrm{abcd}}$ & $1.22 \pm 0.36^{a}$ & $0.86 \pm 0.25^{a}$ & $2.08 \pm 0.62^{a}$ & $1.06 \pm 0.05^{\mathrm{a}}$ & $78.52 \pm 13.32^{\text {cdefg }}$ \\
\hline & Ofer & $57.50 \pm 15.21^{\mathrm{ab}}$ & $63.19 \pm 2.51^{a}$ & $43.29 \pm 16.66^{\mathrm{abcd}}$ & $0.59 \pm 0.14^{a}$ & $0.41 \pm 0.10^{a}$ & $1.00 \pm 0.23^{\mathrm{a}}$ & $0.79 \pm 0.02^{\mathrm{a}}$ & $15.94 \pm 9.56^{\mathrm{ab}}$ \\
\hline & Robusta & $91.40 \pm 1.68^{\text {defgh }}$ & $93.41 \pm 0.11^{\text {efgh }}$ & $11.67 \pm 1.30^{\mathrm{a}}$ & $12.31 \pm 4.17^{b}$ & $8.62 \pm 2.92^{b}$ & $20.93 \pm 7.08^{b}$ & $2.69 \pm 0.04^{a b}$ & $74.73 \pm 14.95^{\text {cdefg }}$ \\
\hline \multicolumn{2}{|l|}{ AVG } & 76.71 & 89.85 & 46.71 & 5.77 & 4.04 & 9.81 & 17.54 & 59.89 \\
\hline \multicolumn{2}{|l|}{ STD } & 14.14 & 9.05 & 27.02 & 11.60 & 8.12 & 19.71 & 31.33 & 34.57 \\
\hline \multicolumn{2}{|l|}{ N } & 6 & 6 & 6 & 6 & 6 & 6 & 6 & 6 \\
\hline \multicolumn{2}{|c|}{ Significance level } & $p<0.001$ & $p<0.001$ & $p<0.001$ & $p<0.001$ & $p<0.001$ & $p<0.001$ & $p<0.001$ & $p<0.001$ \\
\hline
\end{tabular}

Means with different superscripts in the same column differ significantly. Values for fresh peels were reported in De Wit et al. (2019). 
than that reported for cladodes (84.1\%) [44] and fruit pulp (87.9\% average) (Du Toit et al., 2018b). Abou-Elella and Ali (2014) reported \% DPPH values of up to $97.7 \%$ in fresh peels, however, the color of the cultivar was not indicated. In a study by AbdelHameedl et al. (2014) it was found that the juice of the peels had the highest \% DPPH in red fruits (compared to yellow fruit peels) and that DPPH radical scavenging was higher in the peels than in the pulp. For oranges, it was found that the \% DPPH found for the peel was higher than that of the pulp (Divya et al., 2016).

\section{Ascorbic Acid}

Main vitamins in Opuntia spp. include vitamin E, vitamin C, vitamin $\mathrm{K}$, and tocopherols and their contents depend on the cultivar types (Diaz Medina et al., 2007). Being an important nutritional antioxidant, the ascorbic acid content in cactus pear fruits is notably higher than the average ascorbic acid content in regularly consumed fruits such as plums $(7 \mathrm{mg} / 100 \mathrm{~g}$ fresh fruit), nectarines $(10 \mathrm{mg} / 100 \mathrm{~g}$ fresh fruit) and peaches (9 mg/100 g fresh fruit) (Gil et al., 2000). The average ascorbic acid content was $46.7 \mathrm{mg} / 100 \mathrm{~g}$. Ascorbic acid levels in peels ranged from $11.7 \mathrm{mg} / 100 \mathrm{~g}$ in Robusta peel preserves to 109.5 $\mathrm{mg} / 100 \mathrm{~g}$ for dried Robusta peels (Table 1). The lowest values were observed in preserves $(26.2 \mathrm{mg} / 100 \mathrm{~g}$ average), chutney (32.3 mg/100 g average) and juice ( $35 \mathrm{mg} / 100 \mathrm{~g}$ average), with much higher values in fresh peels $(67.1 \mathrm{mg} / 100 \mathrm{~g}$ average $)$ and the highest in dry peels $(73.2 \mathrm{mg} / 100 \mathrm{~g}$ average). Most products and cultivars showed statistically similar results. Interestingly, the two products with the highest ascorbic acid content were fresh and dried peels, while chutney and juice had lower, and very similar, results. Preserves had the lowest ascorbic acid content. This could possibly be ascribed to the heat-sensitivity of ascorbic acid to the high temperatures applied during chutney and preserves production. The levels for peel juice were approximately $50 \%$ that of the values for fresh peel, the same as was found by Gurrieri et al. (2001). Fernández-López et al. (2010) reported ascorbic acid values for fresh peels of $14.5-23.3 \mathrm{mg} / 100 \mathrm{~g}$, while Diaz Medina et al. (2007) reported the highest ascorbic acid values in the red-skinned fruit $(815 \mathrm{mg} / \mathrm{g})$. El-Said et al. (2011) found $590 \mathrm{mg} / \mathrm{kg}$ ascorbic acid in peels, based on FW, although no color was specified. Abdel-Hameedl et al. (2014) found values of $70.17 \mathrm{mg} / 100 \mathrm{ml}$ ascorbic acid in the juice from red cactus pear fruit peels. In a study by Barba et al. (2017) it was found that high pressure processing (HPP) and pulsed-electric field (PEF) treatment on cactus pear juice had higher vitamin C values than the juice receiving a mild pasteurization treatment. In a study done by Divya et al. (2016) it was found that the higher ascorbic acid content in the bitter orange pulp caused the reducing capacity to be higher in the pulp than in the peels.

\section{Betalains}

The cactus pear fruits are characterized by different colors due to the combination of the purple-red betanin and the yellow-orange indicaxanthin pigments (Cerezal and Duarte, 2005). Betalains also contribute most to cactus pear classification (Moussa-Ayoub et al., 2014). Betalains are excellent radical scavengers with an antioxidant activity $3-4 \times$ higher than ascorbic acid, rutin, and catechin (Cai et al., 2005). Betanin extracts were reported to have anticancer activity (Butera et al., 2002). Fruits of cactus pear contain different betalains whose concentration depends on species, cultivar and geographic region (Del Socorro Santos Díaz et al., 2017). Betalains occur in vacuoles as zwitterions, which implicates that peel and pulp amounts will differ. Heat degradation was also described, although different conditions to that applied in the current study (Damodaran and Parkin, 2017). A value of $39.3 \mathrm{mg} / 100 \mathrm{~g} \mathrm{FW}$ was reported for O. ficus-indica fruits (no color mentioned) and $80 \mathrm{mg} / 100 \mathrm{~g}$ betacyanin for $O$. stricta fruits (Patil and Dagadkhair, 2019). Beetroot contains $\approx 50 \mathrm{mg} / 100 \mathrm{~g}$ betanin, while purple cactus pear may contain up to $100 \mathrm{mg} / 100 \mathrm{~g}$ betanin FW. In general, the betacyanin $(\mathrm{Bc})$ values were higher than the betaxanthin $(\mathrm{Bx})$ values $(5.77$ vs. $4.04 \mathrm{mg} / \mathrm{kg}$ ). Robusta (purple cultivar) had the highest Bc values in all the products, followed by Meyers (red fruit peel). Although not significantly different, Nepgen (green peel) had the lowest $\mathrm{Bc}$ values. Dried and fresh products (averages of 10.31 and $10.74 \mathrm{mg} / \mathrm{kg}$, respectively) had the highest values, followed by preserves $(3.53 \mathrm{mg} / \mathrm{kg})$ and chutney $(2.61 \mathrm{mg} / \mathrm{kg})$, and lastly juice $(1.66 \mathrm{mg} / \mathrm{kg})$. Interestingly, Bx contents did not follow the same pattern as observed for $\mathrm{Bc}$, with the highest average values observed in fresh peels $(7.52 \mathrm{mg} / \mathrm{kg})$, followed by dried $(7.22 \mathrm{mg} / \mathrm{kg})$ and preserves $(2.47 \mathrm{mg} / \mathrm{kg})$, with the lowest values in chutney $(1.83 \mathrm{mg} / \mathrm{kg})$, and juice $(1.16 \mathrm{mg} / \mathrm{kg})$. Bx values were the highest in Robusta (purple peel) followed by the red Meyers and orange Gymno-Carpo fruit peels. The values for betalains (betacyanins + betaxanthins) were generally lower in peel (average of $13.57 \mathrm{mg} / \mathrm{kg}$ ) than in fruit pulp $(18.52 \mathrm{mg} / \mathrm{kg}$ average) and cladodes (16.17 mg/kg average) (Du Toit et al., 2018a,b). The lowest Bc and Bx values were found in Nepgen (as was expected), which is a green fruit/peel. Abou-Elella and Ali (2014) reported betacyanin values of 2.94 and betaxanthin values of $2.06 \mu \mathrm{g} / \mathrm{ml}$ in cactus pear fruit peels. Yellow cultivars contained, according to Butera et al. (2002), the highest amounts of betalains, followed by red and white cultivars, while in the current study, purple and red cultivars contained the highest concentrations of betalains, followed by orange and lastly green cultivars. Interestingly, it was reported by Mena et al. (2018) and Amaya-Cruz et al. (2018) that Bc was only found in red cactus pear peel and that red peels showed more Bx contents than yellow and green fruit peels. These authors also reported a greater variety in Bx compounds in the red peels than that found in green and yellow-orange peels. According to Moussa-Ayoub et al. (2014) red fruit peels contains mainly Bc, while yelloworange fruit peels contain mainly $\mathrm{Bx}$. According to these authors, green fruit cultivar peels contained no betalains. In a study by Barba et al. (2017) it was found that high pressure processing (HPP) and pulsed-electric field (PEF) treatment on juice had a similar effect on $\mathrm{Bc}$ than a mild pasteurization treatment, i.e., no difference between HPP and PEF and pasteurization on Bc.

\section{Carotenoids Measured as $\beta$-Carotenes}

Carotenoids represent the major water-insoluble pigment in the peels (El-Said et al., 2011). $\beta$-carotene is pro-vitamin A, which play an important role in cell integrity. Yellow fruits, in general, have higher carotenoid concentrations than other colored fruit (Fernández-López et al., 2010). Carotenoids contribute to the 
appearance and antioxidant content, and combat human chronic diseases (Jaramillo-Flores et al., 2003; Abou-Elella and Ali, 2014). Although not very high in cactus pear fruits, they contribute to antioxidant properties. The highest carotenoid contents were found in yellow-skinned cactus pear fruit $(23.7 \mathrm{mg} / \mathrm{g}$ ) (Diaz Medina et al., 2007). It has been reported that processed products often contain similar amounts of carotenoids than the fresh counterparts (Rickman et al., 2007). Carotenoid values were higher in marmalade than in the fresh fruit, especially the $\beta$-carotene and lutein (Leopoldo et al., 2012). Values of 2.97 $\mathrm{mg} / 100 \mathrm{~g}$ were found in Egyptian prickly pear peels, although no color was mentioned (El-Said et al., 2011).

Carotenoid levels in the cactus pear peel products under study varied from $0.51 \mu \mathrm{g} / \mathrm{g}$ (Nepgen, green, chutney) to $83.3 \mu \mathrm{g} / \mathrm{g}$ (Ofer, orange, dried). In general, very high contents were found in dried products $(80 \mu \mathrm{g} / \mathrm{g})$, while much lower values were found in fresh $(4.04 \mu \mathrm{g} / \mathrm{g})$, preserves $(1.6 \mu \mathrm{g} / \mathrm{g})$, juice $(1.4 \mu \mathrm{g} / \mathrm{g})$, and chutney $(1.2 \mu \mathrm{g} / \mathrm{g})$. The high levels could be as a result of the concentrated nature of the dried peel. Robusta was the cultivar with the highest values for all products, followed by Meyers and Gymno-Carpo with very little difference between the remaining two cultivars. Fernández-López et al. (2010) reported total carotenoid values of $2.58-6.68 \mu \mathrm{g} / \mathrm{g}$ for cactus fruit (unpeeled). The average carotenoid value $(17.5 \mu \mathrm{g} / \mathrm{g})$ reported for the peels and its products were higher than that reported for the pulp carotenoid value $(4.26 \mu \mathrm{g} / \mathrm{g})$ and noticeably lower than that reported for the cladodes $(36.9 \mu \mathrm{g} / \mathrm{g}$ ) (Du Toit et al., 2018a,b) (Table 1). Interestingly, it seems as if the contributing effect of the spices added to the chutney was negligible when compared to preserves and juice. Cano et al. (2007) investigated the carotenoids in the peels of red and yellow-orange cactus pear fruit and reported nine xanthophylls and four hydrocarbon carotenes. The main carotenoid in the peel was (all-E)-lutein and (all-E)- $\beta$-carotene. Higher values (16.48-19.2 $\mu \mathrm{g} / 100 \mathrm{FW})$ were found in the peel than in the pulp. Amaya-Cruz et al. (2018) found the greatest variety of carotenoids in the green peel than the other peel colors.

\section{Total Phenolics}

Flavonoids are secondary metabolites and are categorized in different classes such as alkaloids, terpenoids, and phenolics. Its antioxidant properties are ascribed to their ability to reduce free radical formation and to scavenge free radicals (Panche et al., 2016). They are very effective against lipid peroxidation that causes diseases such as atherosclerosis, diabetes, hepatotoxicity, inflammation and aging. Phenolic compounds, including their functional derivatives, can be defined as substances possessing an aromatic ring, carrying one or more hydroxyl groups. Their chemical structures and concentrations are variable and depend on variety, ripeness stage and kind of plant tissue (Wallace, 1986). Flowers and peels could exhibit higher phenolic contents than fruit and cladodes, with about $45.7 \mathrm{~g} / 100 \mathrm{~g}$ FW. It is therefore recommended to exploit these materials to obtain biocompounds with antioxidant characteristics (El-Mostafa et al., 2014). Antioxidant properties of phenols are attributed to their redox properties-they act as reducing agents, $\mathrm{H}_{2}$ donators, singlet oxygen quenchers and metal chelators (Abdel-Hameedl et al., 2014). Phenolics are reckoned to be the main antioxidants in cactus pears (Abdel-Hameedl et al., 2014; Moussa-Ayoub et al., 2014). Polyphenolics are more stable against radicals than vitamins (Patil and Dagadkhair, 2019). Flavonoids (glycosilated flavols, dihydroflavonols, flavones, and flavonols) are more efficient antioxidants than vitamins because phenolic compounds are able to delay pro-oxidative effects in proteins, lipids and DNA because of the generation of stable radicals (Shahidi and Wanasundara, 1992). Flavonoids present in Opuntia ficus-indica include kaempferol, quercitin, narcissin, dihydro-kaempferol, dihydroquercitin and eriodictyol and total phenolic values of $218 \mathrm{mg}$ GAE/100 g FW and total flavonoid values of $19.4 \mathrm{mmol}$ quercitin/ g sample FW were reported (Patil and Dagadkhair, 2019). Phenolics were higher in processed peel products than fresh peels (Table 1). In general, dried peels had the highest content of total phenolics $(96.7 \mathrm{mg} / \mathrm{kg})$, followed by chutney $(78.6 \mathrm{mg} / \mathrm{kg})$, while preserves $(47.1 \mathrm{mg} / \mathrm{kg})$ and juice $(53.5$ $\mathrm{mg} / \mathrm{kg}$ ) had values in a similar range with fresh peels having the lowest values $(23.5 \mathrm{mg} / \mathrm{kg})$. Chutney and dried products had the highest contents of phenolics (dried Meyers peel $100.96 \mathrm{mg} / \mathrm{kg}$ and Robusta $126.82 \mathrm{mg} / \mathrm{kg}$ ). Juice had very similar results in all cultivars $(47.74-59.56 \mathrm{mg} / \mathrm{kg})$, while the values in preserves were not consistent (Table 1). Overall though, there were very high individual results but no one cultivar could be singled out as having the highest phenolic content across the different peel products. The average total phenol value found for all products $(59.9 \mathrm{mg} / \mathrm{kg}$ ) were lower than that reported for the pulp and its products (97.79 mg/kg) (Du Toit et al., 2015, 2018b) as well as for fresh cladodes and its preserved products (130.55 $\mathrm{mg} / \mathrm{kg}$ ) (Du Toit et al., 2018b). In products such as chutney, preserves and juice, the possible effect of the added ingredients and spices, as well as the higher temperature, on the total phenolic content could be speculated on. The presence of phenol compounds such as alicin in garlic and shogao in ginger was reported to contribute to antioxidant activity (Hossain et al., 2008). Total phenolic values of 164.6-218.8 mg GAE/100 g was found by Fernández-López et al. (2010), which were higher in the red skin varieties than in peaches, plums and nectarines. Peels contain higher amounts of phenolics, since phenolics have a tendency to accumulate in the dermal tissues of plant bodies because of their potential role in protection against UV radiation. They also act as attractants in fruit dispersals and as defensive chemicals against pathogens and predators. Cardador-Martínez et al. (2011) reported higher values $(376 \mathrm{mg} / \mathrm{kg}$ ) in unripe greenyellow cultivars than in red-purple $(44 \mathrm{mg} / \mathrm{kg}$ ) cultivars, while Abou-Elella and Ali (2014) reported values between $221.3 \mu \mathrm{g}$ gallic acid/100 g and $1507 \mu \mathrm{g}$ gallic acid/100 g dry weight. It was found by Divya et al. (2016) that the peel extracts of bitter orange had higher antioxidant activity than the pulp extracts. This was attributed to the higher concentrations of phenolic acids and their derivatives in the peels. Phenolic compounds content vary in different plant parts. An interesting observation was made in strawberries, where achenes (real dry fruits on strawberries) contained 10x more phenolics that the fruit flesh (Ariza et al., 2017). As already mentioned, boiling of onions resulted in lower losses of flavonoids than for example frying. Dehydrated onions contained low amounts of flavonoids. The size, as well as the 
distribution in the onion bulb affected the flavonoid content (Lee et al., 2008). Different results were reported by various authors. Amaya-Cruz et al. (2018) reported the presence of 68 extractable polyphenols and 15 hydrolysable polyphenols in the peel of green, yellow-orange and red cactus pear fruit. Green peels had the highest content of extractable polyphenols, while the peel of green and yellow-orange fruit contained the most hydrolysable polyphenols. Betalains, carotenoids and phytochemical contents were the highest in the red peels. Total phenolics found by these authors were $30 \%$ higher in the green peel $(12.28 \mathrm{GAE} \mathrm{mg} / \mathrm{g})$ than in the yellow-orange (8.62 GAE mg/g) and red peel (9.64 GAE $\mathrm{mg} / \mathrm{g}$ ) and were similar to values reported by Jiménez-Aguilar et al. (2015) (9.94-12.75 GAE mg/g). These authors also stated that total phenolics were higher in green and yellow-orange peels than in red peels. According to them, green peels would have a greater beneficial effect on health than the red and yellow-orange peels since it contains a greater diversity, variety and abundance of flavonols and phenolic acids than red and yellow-orange peels. Jiménez-Aguilar et al. (2015) mentioned that peels contained higher TP than pulp, seeds or juice, while Moussa-Ayoub et al. (2014) reported the lowest TP values found in green colored cactus pear peels compared to the red and yellow-orange peels. These authors also reported that cultivars from South Africa had higher phenolic contents than the Egyptian and Sicilian cultivars studied. Abdel-Hameedl et al. (2014) reported highest values in red fruit peels $(1152.97 \mathrm{mg} \mathrm{GAE} / 100 \mathrm{ml})$, higher than in yellow fruit peels (786.01 mg GAE/100 ml).

Regarding flavonols, it was found by Moussa-Ayoub et al. (2014), that fruit color did not influence the flavonol profile and that green and yellow-orange cultivars produced similar profiles. Red fruits however, contained higher contents of flavonol glycosides compared to yellow-orange and green cultivars. The two cultivars from South Africa showed the highest flavonol contents and thus the effect of location on antioxidant content. Surprisingly, the pulp of O. ficus-indica contains no flavonols, however, flavonols such as isorhamnetin occurs exclusively in the fruit's peels (2.2-4.1 mg/g DW) and might be higher than that found in some other common fruits (Moussa-Ayoub et al., 2014). Conflicting results were reported by Amaya-Cruz et al. (2018) who found higher flavonoid contents in green and yelloworange cultivars than in the red cultivar, while Abdel-Hameedl et al. (2014) found that flavonoids and flavonols are higher in red peels than in yellow peels, but the total flavonoids and flavonols in pulp of red and yellow peels are higher than in the peel of red and yellow peels. Furthermore, flavonols were higher in the peels than in the pulp of cactus pear fruit and higher in peels from thornless cultivars than peels from spiny cultivars (Barba et al., 2017).

\section{PCA of Cultivar and the Antioxidants Properties of Cactus Pear Peel}

In Figure 1, F1 and F2 explained $72.80 \%$ of the variation (F1: $50.62 \%$; F2: $22.18 \%$ ). It can be seen that products, rather than cultivars, seem to cluster together, e.g., juices and fresh peels (close to 0), chutneys (top left quadrant), preserves (left bottom quadrant) and dried peels (top right quadrant). Products on the positive side of Factor 1 are mostly associated with the antioxidants. It is evident that Robusta and its products cluster together (bottom right quadrant) as well as with betalains (Bc, Bx and $\mathrm{Bc}+\mathrm{Bx})$. Robusta is also the only cultivar where its products cluster together. It is also clear that \% DPPH, carotenoids and phenolics are grouped together in the upper right quadrant, with $\%$ chelating activity closely correlated with ascorbic acid. Dried products from all cultivars correlated closely with \% DPPH, carotenoids and phenolics, especially dried peel from GymnoCarpo (orange), Ofer (orange), Meyers (red) and Nepgen (green). Furthermore, it is also visible that red and orange preserves form a cluster, while green preserves and chutney from all cultivars cluster together. Mostly fresh peels and juices cluster together. The position of the vectors in Factor 1 indicated a high correlation between all antioxidants. It was reported that DPPH correlated highly with phenolics and flavonoids (Butera et al., 2002), while ascorbic acid showed a good correlation with antioxidant activity. According to Patil and Dagadkhair (2019) ascorbic acid is responsible for $30-40 \%$ of antioxidant activity in cactus pear fruit. This correlation is also evident in the current study with ascorbic acid clustering with \% chelating activity. Total phenolics correlated linearly with reducing power, free radical scavenging and total antioxidant activity (Abdel-Hameedl et al., 2014) and red peel and pulp had a higher DPPH radical scavenging ability than yellow peel and pulp, implicating a higher antioxidant activity in red peels than in yellow peels. Divya et al. (2016) reported higher retention of total phenolics in pickles than in sweet preserves of bitter orange peels and attributed this trend to heat processing causing more destruction than mechanical processing (destruction). The antioxidant activity of sweet preserves was higher than that of pickles. This was attributed to the liberation of low molecular weight antioxidants on thermal treatment. In the present study, chutney had higher total phenolics than juices and preserves, all products undergoing a heat treatment. It is also known that phenolic compounds may bind to food proteins covalently and non-covalently. These proteins include mostly milk caseins and soy glycinin and $\beta$ conglycinin (Zhang et al., 2014). It also binds to enzymes such as maltase, lipase, protease (trypsin), usually proteins with regions which are proline-rich (such as found in cereals) and hydrophobic (Zhang et al., 2014). These types of interactions are therefore not expected in cactus pear fruit peels, since only sucrose and stachyose are reported to be present in peels and no starch (El-Said et al., 2011). Different heat treatments have different effects on flavonoid contents as was reported for homeprocessed onions, e.g., while frying resulted in a $23 \%$ loss of flavonoids, baking caused no losses (Lee et al., 2008).

According to Fernández-López et al. (2010) ascorbic acid contributed $68 \%$ to antioxidant activity, but that \% DPPH correlated weakly with betalains (Kugler et al., 2007) and carotenes. However, in the present study, \% DPPH correlated strongly with carotenes and phenolics, but also showed no correlation with betalains. Melgar et al. (2017) found a correlation between DPPH and Bc as well as between DPPH and total phenolics. Antioxidant activity usually correlated strongly with the amount of phenolics. Phenolics in peels are good electron donors and could therefore terminate the radical chain reaction by changing free radicals to more stable products (Butera 


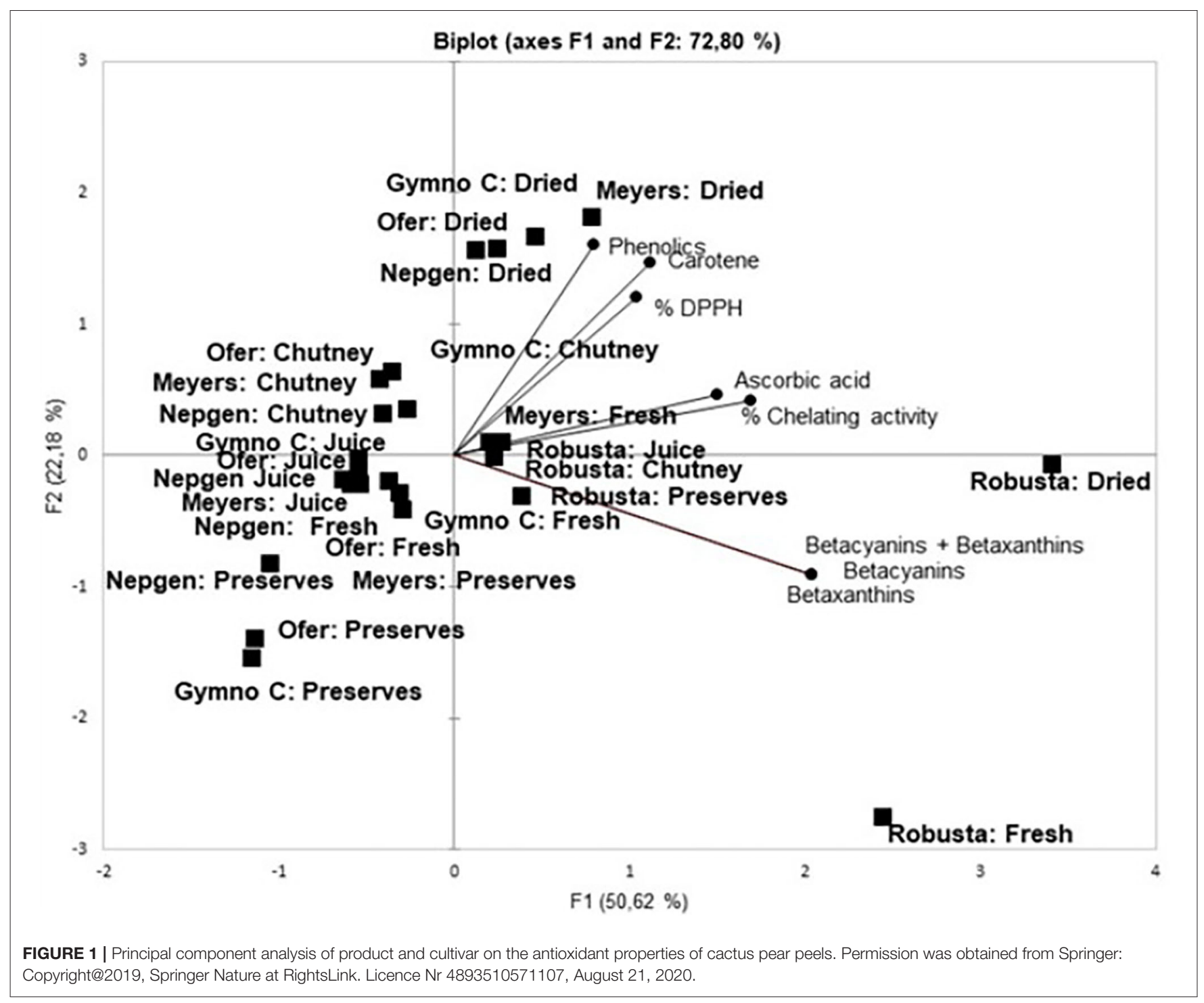

et al., 2002). Divya et al. (2016) also described a high association between total phenols and free radical scavenging and metal ion chelation. The extent of association depended on the polyphenol and the transition metal concentration.

Chain reaction by changing free radicals to more stable products (Butera et al., 2002). Divya et al. (2016) also described a high association between total phenols and free radical scavenging and metal ion chelation. The extent of association depended on the polyphenol and the transition metal concentration.

In the lower left quadrant, it seems that preserved products are clustered together and are not closely related to any of the antioxidants (lowest values in Table 1) while in the upper left quadrant the chutneys seemed to bundle (high values in Table 1). Robusta products were scattered around the betalain content marker (lower right quadrant). Ofer (fresh and juice) (on the left) are not associated with any of the antioxidants.

The PCA figure correlates with data from Table 1, since the products with the highest contents and-capacities were situated nearby the associated markers, whereas products with similar results (chutney and preserves) were bundled together. Peel showed antioxidant content similar to that of fruit (Du Toit et al., 2018b), implying that both fruit and peel would contribute to excellent antioxidant capacity; therefore the peel should be included in processed products such as juice, dried fruit and chutneys, where possible. In the study done by Divya et al. (2016) it was found that the higher antioxidant activity in thermally processed sweet preserves were attributed to the disruption of the peel matrix and caused leaching of phytonutrients. Heat treatment, infrared radiation, fermentation and proteases liberate and activate low molecular weight antioxidants. It was found by these authors that total phenols increased in sweet preserves and chili pickles. An increase in flavonoid content of onions subjected to fluorescent light was also observed by Lee et al. (2008).

The cultivar that could be identified as the best fruit (pulp and peel) from an antioxidant point of view was Robusta. Robusta is not regarded as a popular fresh fruit product, because it lacks sweetness as well as acidity, resulting in an unpleasant 
taste. However, after processing it was transformed into highly acceptable products when sugar and acids were added during processing. It is regarded as the only cactus pear cultivar in South Africa that is unacceptable as fresh fruit but is ideal to be used for processed products. It had high \% DPPH and \% chelating activity readings, very high betalain content and fair amounts of ascorbic acid, carotenes and phenolics.

Drying is the product/processing method of choice, regardless of cultivar. According to Vinson et al. (2005), dried fruit had denser nutrient contents and significantly higher phenolic antioxidant contents than fresh fruit. Dried fruit contains complex carbohydrates, is higher in fiber and has a longer shelf-life and should be recommended to be added to daily diets. Convenience foods are becoming more popular due to the modern lifestyles and consequently, dried products are popular because of the light weight, shelf-stability and small size (Sharma et al., 2011). Opposite results were however reported by Lee et al. (2008), for commercially dehydrated onion products. These were shown to contain very little or no flavonoids. The stability that betalains showed in the current study, with regards to heat and $\mathrm{pH}$, was reported before (Mosshammer et al., 2006). Ascorbic acid may be retained or protected in certain circumstances during processing (Sáenz et al., 2004). Increased carotene contents after processing was reported by JaramilloFlores et al. (2003) while the phenolics displayed high levels in the current study. Consequently, processed cactus pear products may provide more antioxidants to the consumer than fresh fruit as was found by Divya et al. (2016) who reported that sweet preserves, chili pickles and salted pickles all had higher antioxidant activities than the fresh products. Onion by-products added to processed meat products, i.e., pre-cooked pork patties as antioxidants, increased the shelf-life (Cao et al., 2013). Color extracts (anthocyanins) from e.g., blueberries could be used in bakery products to add value and functionality as was reported by Primo da Silva et al. (2019).

\section{CONCLUSIONS}

Cactus pear fruit peels contain high quantities of antioxidants which contribute to considerable antioxidants capacities. It could be concluded that the processed cactus pear peel contains high levels of antioxidant as well as demonstrates high antioxidant capacity. Peels that are normally discarded as waste when only fruit is used, should be utilized for preservation purposes.

Cactus pear fruit peels should be included in processed products such as juice, dried fruit and chutneys, where possible. The best process for peels was drying while the preserves had the lowest values in terms of antioxidants.

Purple fruit peel products contained the highest \% DPPH, $\%$ chelating activity, betalains, carotenoids and phenolics, while

\section{REFERENCES}

Abdel-Hameedl, S. S., Nagaty, M. A., Salman, M. S., and Bazaid, S. A. (2014). Phytochemical, nutritionals and antioxidant properties of two prickly pear in orange and pink fruit peels, ascorbic acid dominated. Purple (first) and orange (second) colored cultivars could be the best choice in terms of antioxidant content. The cultivar that could be pinpointed as the best fruit peel from an antioxidant point of view for preservation was Robusta. It had high \% DPPH and \% chelating activity readings, very high betalain content and fair amounts of ascorbic acid, carotenoids and phenolics. Nepgen (green) was the cultivar with the lowest antioxidant content (not significantly), but demonstrated equally good antioxidant capacity levels. The current study may serve as a benchmark for antioxidant content, activity and retention in processed products, while future studies should focus on the analytical chemistry analysis of antioxidant compounds. Further research must include bioavailability and bioaccessibility studies on these "new" nutraceutical food products. These are defined by Ariza et al. (2017) as: "bioavailability is the ease with which compounds are assimilated by the body and have a positive effect on health, thus the fraction of the given compound or its metabolites that reaches systematic circulation without considering bioactivity", while bioaccessibility is defined as "the fraction of a food constituent that is released from a food matrix in the GIT and becomes available for absorption". Other new innovative products should be developed using processing and preservation methods such as fermentation.

\section{DATA AVAILABILITY STATEMENT}

All datasets generated for this study are included in the article/supplementary material.

\section{AUTHOR CONTRIBUTIONS}

MD: conceptualization, project administration, supervision, and writing-review and editing. $\mathrm{AD}$ : data curation, investigation, and writing-original draft. $\mathrm{AD}$ and $\mathrm{AH}$ : formal analysis. $\mathrm{MD}$ and GO: methodology. $\mathrm{GO}$ and $\mathrm{AH}$ : validation. $\mathrm{AH}$ : visualization. All authors: contributed to the article and approved the submitted version.

\section{FUNDING}

This study was supported by the UFS Strategic Academic Cluster 4 for funding.

\section{ACKNOWLEDGMENTS}

The authors would like to express their sincere gratitude to Dr. H. J. Fouché from the ARC for providing the cactus pear fruit. 
cactus (Opuntia ficus-indica) peels. Biochem. Analyt. Biochem. 3, 1-9. doi: 10.4172/2161-1009.1000158

Amamou, S. A. D., Lazreg, H. B., Hafsa, J. C., Majdoub, H., Rihouey, C., Le Cerf D., et al. (2020). Effect of extraction condition on the antioxidant, antiglycation and $\alpha$-amylase inhibitory activities of Opuntia macrorhiza fruit peels polysaccharides. LWT. 127:109411. doi: 10.1016/j.lwt.2020.109411

Amaya-Cruz, D. M., Pérez-Ramírez, I. F., Delgado-García, J, Mondragón-Jacobo, C., Dector-Espinoza, A., and Reynoso-Camacho, R. (2018). An integral profile of bioactive compounds and functional properties of prickly pear (Opuntia ficus-indica L.) peel with different tonalities. Food Chem. 278, 568-578. doi: 10.1016/j.foodchem.2018.11.031

Ariza, M. T., Reboredo-Rodrígues, P., Cervantes, L., Soria, C., Martínez-Ferri, E., González-Barreiro, C., et al. (2017). Bioaccessibility and potential of phenolic compounds from achenes as a new target for strawberry breeding programs. Food Chem. 248, 155-165. doi: 10.1016/j.foodchem.2017.11.105

Arrizon, J., Calderón, C., and Sandoval, G. (2006). Effect of different fermentation conditions on the kinetic parameters and production of volatile compounds during the elaboration of a prickly pear distilled beverage. J. Ind. Microbiol. Biotech. 33, 921-928. doi: 10.1007/s10295-006-0153-9

Barba, F. J., Putnik, P., Kovačević, D. B., Poojary, M. M., Roohinejad, S., Lorenzo, J. M., et al. (2017). Impact of conventional and non-conventional processing on prickly pear (Opuntia spp.) and their derived products: From preservation of food beverages to valorization of by-products. Trends Food Sci. Technol. 67, 260-270. doi: 10.1016/j.tifs.2017.07.012

Bhagya Raj, G. V. S., and Dash, K. K. (2020). Ultrasound-assisted extraction of phytocompounds from dragon fruit peel: optimization, kinetics and thermodynamic studies. Ultrason. Sonochem. 68:105180. doi: 10.1016/j.ultsonch.2020.105180

Brown, A. (2008). Understanding Food Principles and Preparation. 3rd Edn. eds P. Adams, N. Rose N., and E. Feldman. Manao: Thompson Wadsworth. 79.

Butera, D., Tesoriere, L., Di Gaudio, F., Bongiorno, A., Allegra, M., Pintaudi, A. M., et al. (2002). Antioxidant activities of Sicilian prickly pear (Opuntia ficus-indica) fruit extracts and reducing properties of its betalains: betanin and indicaxanthin. J. Agri. Food Chem. 50, 6895-6901. doi: 10.1021/jf025696p

Cai, Y. Z., Sun, M., and Corke, H. (2005). Characterization and application of betalain pigments from plants of the Amaranthaceae. Trends Food Sci. Technol. 16, 370-376. doi: 10.1016/j.tifs.2005.03.020

Cano, M. P., Gómez-Maqueo, A., Garcia-Cayuela, T., and Welti-Chanes, J. (2007). Characterization of carotenoid profile of Spanish Sanguinos and Verdal prickly pear (Opuntia ficus-indica, spp.) tissues. Food Chem. 237, 612-622. doi: 10.1016/j.foodchem.2017.05.135

Cao, Y., Gu, W., Zhang, J., Chu, Y., Ye, X., Hu, Y., et al. (2013). Effects of chitosan, aqueous extract of ginger, onion and garlic on quality and shelf life of stewed-pork during refrigerated storage. Food Chem. 141, 1655-1660. doi: 10.1016/j.foodchem.2013.04.084

Cardador-Martínez, A., Jiménez-Martínez, C., and Sandoval, G. (2011). Revalorization of cactus pear (Opuntia spp.) wastes as a source of antioxidants. Ciên. Tech. Alimentos Camp. 31, 782-788. doi: 10.1590/S0101-20612011000300036

Casabar, J. T., Unpaprom, Y., and Ramaraj, R. (2019). Fermentation of pineapple fruit peel wastes for bioethanol production. Biomass Conv. Bioref. 9, 761-765. doi: 10.1007/s13399-019-00436-y

Castellanos-Santiago, E., and Yahia, E. (2008). Identification and quantification of betalains from the fruits of 10 Mexican prickly pear cultivars by high-performance liquid chromatography and electrospray ionization mass spectrometry. J. Agri. Food Chem. 56, 5758-5764. doi: 10.1021/ jf800362t

Cerezal, P., and Duarte, G. (2005). Use of skin in the elaboration of concentrated products of cactus pear (Opuntia ficus-indica (L.) Miller). J. Prof. Ass. Cactus Dev. 7, 61-83.

Coetzer, G. M., and Fouché, H. J. (2015). Fruit yield and quality of cactus pear (Opuntia spp.) cultivars in the Central Free State, South Africa. Acta Hort 1067, 89-96. doi: 10.17660/ActaHortic.2015.1067.12

Damodaran, S., and Parkin, K. L. (2017). Fennema's Food Chemistry. 5th Edn. Boca Raton, FL: CRC Press, Taylor \& Francis Group.

De Wit, M., Du Toit, A., Osthoff, G., and Hugo, A. (2019). Cactus pear antioxidants: a comparison between fruit pulp, fruit peel, fruit seeds and cladodes of eight different cactus pear cultivarsb (Opuntia ficus-indica and Opuntia robusta). J. Food Measure. Charac. 13, 2347-2356. doi: 10.1007/s11694-019-00154-Z

De Wit, M., Hugo, A., and Shongwe, N. (2017). Quality assessment of seed oil from selected cactus pear cultivars (Opuntia ficus-indica and Opuntia robusta). J. Food Proc. Pres. 41:e12898. doi: 10.1111/jfpp.12898

De Wit, M., Hugo, A., and Shongwe, N. (2018). South African cactus pear seed oil: a comprehensive study on 42 spineless Burbank Opuntia ficusindica and Opuntia robusta cultivars. Eur. J. Lipid Sci. Tech. 20:1700343. doi: 10.1002/ejlt.201700343

De Wit, M., Hugo, A., Shongwe, N., and Van der Merwe, R. (2016). Effect of cultivar, season and locality on lipid content and fatty acid composition of cactus pear seed oil. SA J. Plant Soil 33, 279-288. doi: 10.1080/02571862.2016.1141335

De Wit, M., Nel, P., Osthoff, G., and Labuschagne, M. T. (2010). The effect of variety and location on cactus pear (Opuntia ficus-indica) fruit quality. Plant Food Human Nutr. 65, 136-145. doi: 10.1007/s11130-010-0163-7

Del Socorro Santos Díaz, M., De La Rosa, A. -P. B., Héliès-Toussaint, E., Guéraud, F., and Nègre-Salvayre, A. (2017). Opuntia spp.: characterization and benefits in chronic diseases. Oxi. Med. Cell Longev. 4, 1-17. doi: 10.1155/2017/8634249

Diaz Medina, E. M., Rodriquez Rodriquez, E. M., and Romero, C. D. (2007). Chemical characterization of Opuntia dillenii and Opuntia ficus indica fruits. Food Chem. 103, 38-45. doi: 10.1016/j.foodchem.2006.06.064

Divya, P. J., Jamuna, P., and Jyothi, L. A. (2016). Antioxidant properties of fresh and processed Citrus aurantium fruit. Cogent Food Sci. Technol. 2:1184119 doi: 10.1080/23311932.2016.1184119

Du Toit, A., De Wit, M., Osthoff, G., and Hugo, A. (2015). Antioxidant content and capacity of fruit from different colour cactus pear $(O$. ficus-indica and O. robusta) cultivars. Acta Hort. 1067, 187-192. doi: 10.17660/ActaHortic.2015.1067.25

Du Toit, A., De Wit, M., Osthoff, G., and Hugo, A. (2018a). Antioxidant properties of fresh and processed cactus pear cladodes from selected Opuntia ficus-indica and $O$. robusta cultivars. SA J. Bot. 118, 44-51. doi: 10.1016/j.sajb.2018.06.014

Du Toit, A., De Wit, M., Osthoff, G., and Hugo, A. (2018b). Relationship and correlation between antioxidant content and capacity, processing method and fruit colour of cactus pear fruit. Food Bioproc. Tech. 11, 1527-1535 doi: 10.1007/s11947-018-2120-7

El Kossori, R. L., Villaume, C. E., El Boustani, E., Sauvaire, Y., and Mejean, L. (1998). Composition of pulp, skin and seeds of prickly pears fruit (Opuntia ficus indica sp.). Plant Foods Hum. Nutr. (Formerly Qualitas Plantarum), 52, 263-270. doi: 10.1023/A:1008000232406

El-Mostafa, K., El Kharrassi, Y., and Badreddine, A. (2014). Nopal cactus (Opuntia ficus-indica) as a source of bioactive compounds for nutrition, health and disease. Molecules 19, 14879-14901. doi: 10.3390/molecules 190914879

El-Said, N. M., Nagib, A. I., Rahman, Z. A., and Deraz, S. F. (2011). Prickly pear [Opuntia ficus-indica (L.) Mill] peels: chemical composition, nutritional value and protective effects on liver and kidney functions and cholesterol in rats. Func. Plant Sci. Biotechnol. 5, 30-35.

Felker, P., Stintzing, F. C., Müssig, E., Leitenberger, M., Carle, R., and Vogt, T. (2008). Colour inheritance in cactus pear (Opuntia ficus-indica) fruits. Ann. App. Biol. 152, 307-318. doi: 10.1111/j.1744-7348.2008.00222.x

Fernández-López, J. A., Almela, L., Obón, J. M., and Castellar, R. (2010). Determination of antioxidant constituents in cactus pear fruits. Plant Food Human Nutr. 65, 253-259. doi: 10.1007/s11130-010-0189-x

Food Preservation (1986). Volksraad Departement van Onderwys en Kultuur Administrasie. Pretoria: Voedselpreservering. Staatsdrukker.

Galati, E. M. (2001). Antiulcer activity of Opuntia ficus indica (L.) Mill. (Cactaceae): ultrastructural study. J. Ethnophar. 76, 1-9. doi: 10.1016/S0378-8741(01)00196-9

Galati, E. M., Mondello, M. R., Guiffrida, D., Dugo, G., Miceli, N., Pergolizzi, S., et al. (2003). Chemical characterization and biological effects of Sicilian Opuntia ficus-indica (L.) Mill. fruit juice: antioxidant and antiulcerogenic activity. J. Agri. Food Chem. 51, 4903-4908. doi: 10.1021/jf030123d

Gil, M. I., Tomás-Barberán, F. A., Hess-Pierce, B., Holcroft, D. M., and Kader, A. A. (2000). Antioxidant activity of pomegranate juice and its relationship with phenolic composition and processing. J. Agri. Food Chem. 48, 4581-4589. doi: 10.1021/jf000404a

Gülçin, I., Elmastat, M., and Aboul-enein, H. Y. (2007). Determination of antioxidant and radical scavenging activity of basil (Ocimum basilicum L. 
Family Lamiaceae) assayed by different methodologies. Phytother. Res. 21, 354-361. doi: 10.1002/ptr.2069

Gurrieri, S., Miceli, L., Lanza, C. M., Tomaselli, F., Bonomo, R. P., and Rizzarelli, E. (2001). Chemical characterization of Sicilian prickly pear (Opuntia ficus indica) and perspectives for the storage of its juice. J. Agri. Food Chem. 48, 5424-5431. doi: $10.1021 /$ jf9907844

Habibi, Y., Mahrouz, M., and Vignon, M. R. (2002). Isolation and structure of Dxylans from pericarp seeds of Opuntia ficus-indica prickly pear fruits. Carboh. Res. 337, 1593-1598. doi: 10.1016/S0008-6215(02)00186-6

Habibi, Y., Mahrouz, M., and Vignon, M. R. (2005). D-Xylans from seed endosperm of Opuntia ficus-indica prickly pear fruits. Comp. Ren. Chim. 8, 1123-1128. doi: 10.1016/j.crci.2004.11.027

Hernández García, F., Coll, L. A., Cano-Lamadrid, M., López Lluch, D., Carbonell Barrachina, A. A., and Legua Murcia, P. (2020). Valorization of prickly pear [Opuntia ficus-indica (L.) Mill]: Nutritional composition, functional properties and economic aspects. Cactaceae Current Trends Future Persp. 92009. doi: 10.5772/intechopen.92009

Hossain, M. B., Brunton, N. P., Barry-Ryan, C., Martin-Diana, A. B., and Wilkinson, M. (2008). Antioxidant activity of spice extracts and phenolics in comparison to synthetic antioxidants. Rasayan J. Chem. 1, 751-756. doi: $10.21427 / \mathrm{D} 7105 \mathrm{D}$

Inglese, P., Basile, F., and Schirra, M. (2002). "Cactus pear fruit production," in Cacti Biology and Uses, ed P. S. Nobel (California: University of California Press), 280. doi: 10.1525/california/9780520231573.003.0010

James, C. S. (1995). Analytical Chemistry of Food. Available online at: http://www. cabdirect.org doi: 10.1007/978-1-4615-2165-5

Jaramillo-Flores, M. E., González-Cruz, L., Cornejo-Mazón, M., Dorantes-Alvarez, L., Gutiérrez-López, G. F., and Hernández-Sánchez, H. (2003). Effect of thermal treatment on the antioxidant activity and content of carotenoids and phenolic compounds of cactus pear cladodes (Opuntia ficus-indica). Food Sci. Tech. Int. 9, 271-278. doi: 10.1177/108201303036093

Jiménez-Aguilar, D. M., López-Martinez, J. M., Hernández-Brenes, C., GutiérrezUribe, J. A., and Welti-Chanes, J. (2015). Dietary fiber, phytochemical composition and antioxidant activity of Mexican commercial varieties of cactus pear. J. Food Comp. Anal. 41, 66-73. doi: 10.1016/j.jfca.2015.01.017

Joubert, E. (1993). Processing of the fruit of five prickly pear cultivars grown in South Africa. Int. J. Food Sci. Tech. 28, 377-387. doi: 10.1111/j.1365-2621.1993.tb01284.x

Kugler, F., Stintzing, F. C., and Carle, R. (2007). Evaluation of the antioxidant capacity of betalainic fruits and vegetables. J. App. Bot. Food Qual. 81, 69-76.

Kuti, J. O. (2000). Antioxidant activity of Opuntia cactus pear. Hort. Sci. 35, 433. doi: 10.21273 /HORTSCI.35.3.433B

Kuti, J. O. (2004). Antioxidant compounds from four Opuntia cactus pear fruit varieties. Food Chem. 85, 527-533. doi: 10.1016/S0308-8146(03)00184-5

Lee, S. U., Lee, J. H., Choi, S. H., Lee, J. S., Ohnisi-Kameyama, M., Kozukue, N., et al. (2008). Flavonoid content in fresh, home-processed, and light-exposed onions and in dehydrated commercial onion products. J. Agric. Food Chem. 56, 8541-8548. doi: 10.1021/jf801009p

Leopoldo, G-C., Santiago, F-K., Luis Arturo, B-P., Norma, G-V., and Aurea, B-N. (2012). Carotenoid content, antioxidant activity and sensory evaluation of lowcalorie nopal (Opuntia ficus-indica) marmalade. J. Food Proc. Pres. 36, 267-275. doi: $10.1111 / j .1745-4549.2011 .00589 . x$

López-González, J. J., Fuentes-Rodríguez, J. M., and Rodríguez-Gámez, A. (1997). Industrializacion de la tuna cardona (Opuntia streptacantha) Prickly pear fruit industrialization (Opuntia streptacantha). J. Prof. Ass. Cactus Dev. 2, 169-175.

Melgar, B., Inês Dias, M., Ciric, A., Sokovic, M., Garcia-Castello, E. M., RodriguezLopez, A. D., et al. (2017). By-product recovery of Opuntia spp. peels: Betalainic and phenolic profiles and bioactive properties. Ind. Crops. Prod. 107, 353-359. doi: 10.1016/j.indcrop.2017.06.011

Mena, P., Tassotti, M., Andreu, L., Nuncio-Jáuregui, N., Legua, P., Del Rio, D., et al. (2018). Phytochemical characterization of different prickly pear (Opuntia ficus-indica (L.) Mill.) cultivars and botanical parts:UHPLC-ESI-MS ${ }^{\text {n }}$ metabolomics profiles and their chemometric analysis. Food Res. Int. 108, 301-308. doi: 10.1016/j.foodres.2018.03.062

Morales, F. J., and Jiménez-Pérez, S. (2001). Free radical scavenging capacity of Maillard reaction products as related to colour and fluorescence. Food Chem. 72, 119-125. doi: 10.1016/S0308-8146(00)00239-9
Mosshammer, M. R., Stintzing, F. C., and Carle, R. (2006). Impact of thermal treatment and storage on color of yellow-orange cactus pear (Opuntia ficus-indica [L.] Mill. cv. 'Gialla') juices. J. Food Sci. 71, 400-406. doi: 10.1111/j.1750-3841.2006.00134.x

Moussa-Ayoub, T. E., Abd El-Hady, E. -S. A., Omran, H. T., and El-Samahy, S. K. (2014). Influence of cultivar and origin on the flavonol profile of fruits and cladodes from cactus Opuntia ficus-indica. Food Res. Int. 64, 864-872. doi: 10.1016/j.foodres.2014.08.021

NCCS 11 (2018). Statistical Software NCSS Version 11.0.20. Kaysville, UT: LLC. Available online at: ncss.com/software/ncss

Panche, A. N., Diwan, A. D., and Chandra, S. R. (2016). Flavonoids: an overview. J. Nutri. Sci. 5:e47. doi: 10.1017/jns.2016.41

Patil, K. V., and Dagadkhair, A. C. (2019). Physicochemical characteristics and antioxidant potential of Opuntia fruit: a review. Phar. Innov. 8, 376-380.

Pérez-Jiménez, J., and Saura-Calixto, F. (2018). Fruit peels as sources of non-extractable polyphenols or macromolecular antioxidants: analysis and nutritional implications. Food. Res. Int. 111, 148-152. doi: 10.1016/j.foodres.2018.05.023

Piga, A. (2004). Cactus Pear : a fruit of nutraceutical and functional importance. $J$. Prof. Ass. Cactus Dev. 9-22.

Piga, A., Del Caro, A., Pinna, I., and Agabbio, M. (2003). Changes in ascorbic acid, polyphenols contents and antioxidant activity in minimally processed cactus pear fruits. LWT - Food Sci. Tech. 36, 257-262. doi: 10.1016/S0023-6438(02)00227-X

Pimienta-Barrios, E. (1994). Prickly pear (Opuntia spp.): a valuable fruit crop for the semi-arid lands of Mexico. J. Arid Envir 28, 1-11. doi: 10.1016/S0140-1963(05)80016-3

Primo da Silva, L., Pereira, E., Prieto, M. A., Simal-Gandara, J., Pires, T. C. S. P., Alves, M. J., et al. (2019). Rubus ulmifolius Schott as a novel source of food colorant: extraction, optimization of coloring pigments and incorporation in a bakery product. Molecules 24:1181. doi: 10.3390/molecules24112181

Ramadan, M. F., and Mörsel, J.-T. (2003b). Recovered lipids from prickly pear [Opuntia ficus-indica (L.) Mill] peel: a good source of polyunsaturated fatty acids, natural antioxidant vitamins and sterols. Food Chem. 83, 447-456. doi: 10.1016/S0308-8146(03)00128-6

Ramadan, M. F., and Mörsel, J. -T. (2003a). Oil cactus pear (Opuntia ficus-indica L.). Food Chem. 82, 339-345. doi: 10.1016/S0308-8146(02) 00550-2

Rickman, J. C., Bruhn, C. M., and Barrett, D. M. (2007). Nutritional comparison of fresh, frozen and canned fruits and vegetables. Part 1 . Vitamins $\mathrm{C}$ and $\mathrm{B}$ and phenolic compounds. J. Sci. Food Agri. 87, 1185-1196. doi: 10.1002/js fa. 2824

Ryan, L., and Prescott, S. L. (2010). Stability of the antioxidant capacity of twenty-five commercially available fruit juices subjected to an in vitro digestion. Int. J. Food Sci. Tech. 45, 1191-1197. doi: 10.1111/j.1365-2621.2010. 02254.x

Sacchetti, G., Cocci, E., Pinnavaia, G., Mastrocola, D., and Rosa, M. D. (2008). Influence of processing and storage on the antioxidant activity of apple derivatives. Int. J. Food Sci. Tech. 43, 797-804. doi: $10.1111 / j .1365-2621.2007 .01518 . x$

Sáenz, C. (2015). Recent advances in cactus agro-industries: ingredients and foods. CACTUSNET Newsletter Special Issue 14, 44-49.

Sáenz, C., Sepúlveda, E., and Matsuhiro, B. (2004). Opuntia spp. mucilage’s: a functional component with industrial perspectives. J. Arid Envir. 57, 275-290. doi: 10.1016/S0140-1963(03)00106-X

Salisbury, F., and Ross, C. (1991). Plant Physiology. 4th Edn. Beverly: Wadsworth Publishing Company, 481.

Shahidi, F., and Wanasundara, P. K. (1992). Phenolic antioxidants. Crit. Rev. Food Sci. Nutr. 32, 67-103. doi: 10.1080/10408399209527581

Sharma, K. D., Sharma, R., and Attri, S. (2011). Instant value added products from dehydrated peach, plum and apricot fruits. Ind. J. Nat. Prod. Resour. 2, 409-420.

Stintzing, F. C., Herbach, K. M., Mosshamer, M. R., Carle, R., Sellapan, S., and Akoh, C. C. (2005). Color, betalain pattern, and antioxidant properties of cactus pear (Opuntia spp.) clones. J. Agri. Food Chem. 53, 442-452. doi: $10.1021 /$ jf048751y

Sumaya-Martínez, M. T., Cruz-Jaime, S., Madrigal-Santillán, E., García- Paredes, J. D., Cariño-Cortés, R., and Cruz-Cansino, N. (2011). Betalain, acid ascorbic, 
phenolic contents and antioxidant properties of purple, red, yellow and white cactus pears. Int. J. Mol. Sci. 12, 6452-6468. doi: 10.3390/ijms12106452

Tesoriere, L., Fazzari, M., Allegra, M., and Livrea, M. A. (2005). Biothiols, taurine and lipid-soluble antioxidants in the edible pulp of Sicilian cactus pear (Opuntia ficus-indica) fruits and changes of bioactive juice components upon industrial processing. J. Agri. Food Chem. 53, 7851-7855. doi: 10.1021/ jf050636f

Vinson, J. A., Zubik, L., Bose, P., Samman, N., and Proch, J. (2005). Dried fruits: excellent in vitro and in vivo antioxidants. J. Am. Coll. Nutr. 24, 44-50. doi: 10.1080/07315724.2005.10 719442

Wallace, R. S. (1986). Biochemical taxonomy and the Cactaceae. Cactus Succ. J. $58,35-38$.

Yashin, A., Yashin, Y., Xia, X., and Nemzer, B. (2017). Antioxidant activity of spices and their impact on human health: a review. Antioxidants 6:70. doi: 10.3390/antiox6030070
Zhang, H., Yu, D., Sun, J., Liu, X., Jiang, L., Guo, H., et al. (2014). Interaction of plant phenols with food macronutrients: characterization and nutritional-physiological consequences. Nutr. Res. Rev. 27, 1-15. doi: $10.1017 /$ S095442241300019X

Conflict of Interest: The authors declare that the research was conducted in the absence of any commercial or financial relationships that could be construed as a potential conflict of interest.

Copyright $\odot 2020$ De Wit, Du Toit, Osthoff and Hugo. This is an open-access article distributed under the terms of the Creative Commons Attribution License (CC BY). The use, distribution or reproduction in other forums is permitted, provided the original author(s) and the copyright owner(s) are credited and that the original publication in this journal is cited, in accordance with accepted academic practice. No use, distribution or reproduction is permitted which does not comply with these terms. 